\title{
Constituir-Se Terapeuta Ocupacional em Contexto Hospitalar Pediátrico: Experiências de Residentes Multiprofissionais
}

\author{
Klein, Taiane Maiara; Franco, Mariana de Paiva; Braga, Cláudia Pellegrini; Galheigo, \\ Sandra Maria \\ Programa de Residência Multiprofissional em Promoção da Saúde e Cuidado na Atenção Hospitalar - \\ Faculdade de Medicina da Universidade de São Paulo — taianeklein@gmail.com
}

Introdução:O hospital caracteriza-se por modo hegemônico de agir marcado por ações profissionais procedimento-centradas, onde o sujeito da atenção se vê reduzido a um diagnóstico, problema, intervenção ou caso. Trata-se de um lugar onde predomina o uso de tecnologias duras e leve-duras, no qual o saber e o poder são domínios profissionais. a humanização do ambiente hospitalar implica em modos de resistência e criação para transformar procedimentos em cuidado, produzindo afetação mútua entre usuário e cuidador. a residência multiprofissional abre uma porta para a experimentação de novos modos de cuidar de si e dos outros. Objetivos: Refletir sobre o percurso de formação técnica, ética e política de residentes de terapia ocupacional em saúde da criança e do adolescente. Métodos: Análise temática dos diários de campo referentes aos conteúdos das disciplinas, das discussões clínicas e das experiências do cotidiano, apresentados por terapeutas ocupacionais em programa de residência multiprofissional, realizada em unidades pediátricas de hospitais de média e alta complexidade na cidade de São Paulo. Resultados:Cinco unidades temáticas foram identificadas: (1) Aproximações-tensões com o universo hospitalar: 0 hospital é um ambiente adverso e dinâmico, em que o afastamento do território e a fragilidade da articulação da rede têm que ser constantemente tensionados. (2) Construção da valise teóricometodológica: a atuação hospitalar demanda uma formação teórico-prática que problematize instituídos e que possibilite uma atuação nos princípios da humanização, da ética e integralidade do cuidado. (3) Constituir-se cuidador em contextos hospitalares: dificuldades em compor com a dureza do hospital, porém, operar pela singularização permite o fazer humanizado. o suporte teórico, supervisão e aprendizagem prática permitem constituir um modo próprio de ser terapeuta ocupacional em contexto hospitalar pediátrico, pautado na humanização e na ética do cuidado. (4) o cuidado de si: a relação de cuidado e a aproximação com situações de sofrimento exigem um novo corpo, e cuidado de si do terapeuta. (5) Construindo a autonomia e o lugar profissional: Conquistar o lugar da Terapia Ocupacional na equipe multiprofissional mistura-se com a construção da autonomia do residente no serviço. Há relevância no contato com pares multiprofissionais para a obtenção da autonomia e do reconhecimento do papel do residente. (6) a multi e a interprofissionalidade como horizonte: um desafio que amadurece em propostas de integração e ações coletivas entre profissionais, mas que não acontecem por limites do serviço. Conclusões: a formação técnica, ética e política implica em exercitar a delicadeza do cuidado no cotidiano hospitalar, em acolher e escutar o outro, seja usuário ou profissional e em construir diálogos e projetos com os atores envolvidos. a residência possibilita, além do ganho profissional, crescimento pessoal do residente que se dá pelas afetações que ousa experimentar.

Klein, Taiane Maiara; Franco, Mariana de Paiva; Braga, Cláudia Pellegrini; Galheigo, Sandra Maria. Constituir-Se Terapeuta Ocupacional em Contexto Hospitalar Pediátrico: Experiências de Residentes Multiprofissionais. In: Anais do Congresso Internacional de Humanidades \& Humanização em Saúde [= Blucher Medical Proceedings, num.2, vol.1]. São Paulo: Editora Blucher, 2014. ISSN 2357-7282

DOI 10.5151/medpro-cihhs-10708 